\title{
Type V Protein Secretion: Simplicity Gone Awry?
}

\author{
Mickaël Desvaux, Nicholas J. Parham \\ and lan R. Henderson*
}

Bacterial Pathogenesis and Genomics Unit, Division of Immunity and Infection, The University of Birmingham, The Medical School, Edgbaston, Birmingham B15 2TT, UK

\begin{abstract}
Since its discovery in the late 1980's, the family of secreted proteins termed the autotransporters has been expanding continuously to become the largest group of secreted proteins in Gram-negative bacteria. The type $\mathbf{V}$ secretion pathway, which includes the autotransporters (type $V_{a}$ ) together with the twopartner secretion system (type $V_{b}$ ) and the Oca family (type $V_{c}$ ), can be defined by secreted proteins that are (i) translocated across the outer membrane via a transmembrane pore formed by a $\beta$-barrel and (ii) contain all the information required for translocation through the cell envelope. In the light of new discoveries and controversies in this research field, the secretion process of autotransporters, or the type $V_{a}$ secretion system, will be discussed here and placed in the context of the more general field of bacterial protein translocation.
\end{abstract}

\section{Introduction}

In contrast, to Gram-positive bacteria which possess only one biological membrane, the cell envelope of Gram-negative bacteria is composed of two asymmetric biological membranes: (i) the inner membrane, also called the cytoplasmic or periplasmic membrane, and (ii) the outer membrane. This double membrane system sandwiches the periplasmic space between them. Thus, proteins which are targeted for secretion must traverse the periplasm and both membranes. To date five major secretion systems, numbered from I to $\mathrm{V}$, which permit the secretion of soluble proteins have been described for Gram-negative bacteria (Salmond and Reeves, 1993; Henderson et al., 2000c). This classification is based on similarities found among the protein components and the mechanism of protein translocation utilised to traverse the outer membrane. Therefore, the secretion pathways in Gram-negative bacteria are categorized primarily by their outer membrane translocation mechanisms which govern translocation of proteins to the extracellular milieu.

For an in-depth understanding of the type I, II, III and IV secretion pathways we refer the reader to other excellent and updated reviews (Stathopoulos et al., 2000; Thanassi and Hultgren, 2000; Christie, 2001; Sandkvist, 2001; Buttner and Bonas, 2002; Sexton and Vogel, 2002; Andersen,

*For correspondence. Email i.r.henderson@bham.ac.uk.
2003; Blocker et al., 2003). The type I secretion system can be exemplified by the HlyA haemolysin of Escherichia coli. The secretion pathway involves an oligomeric complex composed of an inner membrane ATP-binding cassette $(A B C)$ exporter (IM-ABC), a membrane fusion protein (MFP) and an outer membrane TolC homologue. The type II secretion system is a two-step process and has been best studied for the pullulanase enzyme, PulA, from Klebsiella oxytoca. It involves the export of proteins across the inner membrane via the Sec system and subsequently the transport of the effector molecule across the outer membrane. A dedicated secretion apparatus called the secreton, which is composed of up to 16 different gene products and at some stage spans the entire cell envelope, mediates this latter step. The type III secretion pathway has been well characterised in Salmonella and Yersinia. It comprises a complex apparatus of proteins that assembles into a highly regulated channel through both the inner and outer membranes forming a needle-like structure. This apparatus, also called the injectisome or molecular needle, is designed to secrete proteins not only into the extracellular milieu but also directly into a target eukaryotic cell. The type IV secretion system is related to the systems involved in conjugative transfer of DNA and allows the secretion of nucleoprotein complexes e.g. Agrobacterium T-DNA, multisubunit toxins such as the pertussis toxin (PT), or monomeric proteins like RecA. Based on sequence homology, this pathway has recently been divided into two subclasses (Christie and Vogel, 2000): (i) the type $I V_{a}$ corresponds to machinery assembled from VirB homologues of Agrobacterium tumefaciens (ii) the type $I V_{b}$ corresponds to functional secretion system assembled from Tra homologues of Incl Collb-P9 plasmid of Shigella flexneri.

The type $\mathrm{V}$ secretion system is one of the most recently described pathways permitting the translocation of proteins into the extracellular milieu. Paradoxically, it possesses the simplest secretion apparatus and represents the largest family of protein-translocating outer membrane porins in Gram-negative bacteria (Yen et al., 2002). This system was first described for the IgA1 protease produced by Neisseria gonorrhoeae (Pohlner et al., 1987). By elucidating the relationship between the $\lg \mathrm{A} 1$ protease gene and its extracellular product, it was shown that the protein precursor contains three functional domains: (i) the $\mathrm{N}$-terminal leader, which is assumed to initiate the inner membrane transport of the precursor, (ii) the mature part of the protein, i.e. the extracellular functional domain, and, (iii) a C-terminal helper domain which is essential for extracellular secretion. Based on their evidence Pohlner et al (Pohlner et al., 1987) proposed a model for secretion in which the helper domain serves as a pore for the secretion of the protease domain through the outer membrane. The protease acquires its active conformation as its extracellular transport proceeds and is further released from the membrane-bound helper by autoproteolysis. The soluble proform further matures into 
the $106-k D a \operatorname{lgA} 1$ protease and a small stable $\alpha$-protein. In this model, neither accessory factors for transit from the periplasm to the bacterial surface nor external energy for the secretion across the outer membrane are required. Therefore, this secretion system and the proteins secreted via this pathway have been designated autotransporters. Secreted proteins belonging to the type $\mathrm{V}$ secretion family (a) contain all the information for translocation through the cell envelope and/or require a single accessory factor and (b) translocate across the outer membrane via a transmembrane pore formed by a $\beta$-barrel structure (Henderson et al., 1998; Thanassi and Hultgren, 2000). The proteins secreted by this pathway possess unifying characteristics including: (i) an N-terminal signal sequence for inner membrane translocation, (ii) a functional passenger domain that can be surface-exposed or released into the extracellular milieu, (iii) a linker region necessary for translocation of the passenger domain through the outer membrane, (iv) a C-terminal region involved in the formation of a transmembrane pore. Based on these and others criteria, the two-partner system (TPS) has been grouped under the type $\mathrm{V}$ secretion umbrella as a distinct subgroup (Henderson et al., 2000a,b; Jacob-Dubuisson et al., 2000). In contrast to the autotransporter pathway where the protein is produced as a single polypeptide, in the TPS the passenger domain (also called the exoprotein) and the pore forming $\beta$-domain (also called transporter domain) are translated as two separate proteins, respectively referred as TpsA and TpsB family members (Jacob-Dubuisson et al., 2001). From an evolution point (Danchin, 2003), it is still difficult to discriminate between divergent evolution from a common ancestor or convergent evolution towards a similar solution for secretion of large proteins across the outer membrane (Henderson et al., 2000a,b; Jacob-Dubuisson et al., 2000). Nevertheless, it appears from homology comparisons and the similarities in the gross anatomy of the autotransporter and TPS secretion pathways that the two pathways are related. Thus, in a manner similar to the type IV secretion pathway (Christie and Vogel, 2000), it has been proposed to classify autotransporter protein secretion as type $V_{a}$ secretion and the TPS in the subgroup of type $V_{b}$ (Desvaux et al., 2003). More recently, the Yersinia adhesin YadA has been presented as the prototype of a novel class of bacterial adhesin belonging to the Oca (Oligomeric coiled coils adhesin) family (Hoiczyk et al., 2000; Nummelin et al., 2003; Roggenkamp et al., 2003). These family members possess a particular outer membrane topology and should probably be considered as a subfamily of surface-attached oligomeric autotransporters (Roggenkamp et al., 2003). Thus we propose terming this secretion pathway type $V_{c}$. This review will mainly focus on the type $V_{a}$ secretion pathway, i.e. the autotransporters, for which a considerable amount of research has been completed in the past few years. These recent investigations have challenged, questioned and/or reinforced some aspects of the original model of type $\mathrm{V}$ secretion pathway as well as the secretion systems in general. We will first focus on the primary structure of the autotransporters which have been described differently throughout the literature and then summarise the current knowledge regarding the export of autotransporters into the periplasm. Finally, we will described the translocation of the autotransporter through the outer membrane discussing the controversies around the folding state of the precursor, the topology of the $\beta$-barrel, the energy of translocation and the release effector molecule.

\section{The structure of autotransporter proteins}

Autotransporter proteins are synthesized as a single polypeptide containing all the information required for their export and secretion (Henderson et al., 1998). The primary structure of these proteins is basically modular and composed of three main domains: the signal peptide, the passenger domain and the translocation unit (Figure $1 \mathrm{~A})$. During export through the inner membrane, the signal sequence is cleaved and the autotransporter is released as a protein or pro-protein form (depending on whether or not it is cleaved after secretion through the outer membrane) into the periplasm. Translocation through the outer membrane via the translocation unit completes the secretion of the autotransporter from the cytoplasm to the extracellular milieu. Depending on the autotransporter, the passenger domain may be either displayed on the bacterial cell surface or released in the extracellular environment.

At the $\mathrm{N}$-terminus, the signal peptide (also called signal sequence or leader sequence) targets the protein to the inner membrane for its further translocation into the periplasmic space. The signal sequence is composed of three domains (Figure 1A): (i) a positively charged amino terminus or $\mathrm{n}$-domain, (ii) a hydrophobic core region or $\mathrm{h}$ domain, and (iii) a consensus signal peptidase recognition site also called c-domain (Fekkes and Driessen, 1999). However, some autotransporters possess unusual signal sequences (see the following section) (Henderson et al., 1998). A leader peptidase cleaves the signal peptide permitting the release of the pro-protein into the periplasm.

The adjacent domain is the passenger domain (also called $\alpha$-domain, $\mathrm{N}$-passenger domain or $\mathrm{N}$-domain). This domain corresponds to the effector molecule since it performs the extracellular function of the autotransporter protein. The passenger domains are very diverse in sequence and function, but to date they have always been linked to a role in bacterial virulence. They can (i) display enzymatic activity (protease, peptidase, lipase, esterase), (ii) mediate actin-promoted bacterial motility, or act as (iii) adhesins, (iv) toxins or cytotoxins, (v) immunomodulatory proteins, or as discovered more recently, (vi) permitting maturation of another virulence protein (Henderson et al., 1998; Coutte et al., 2001; Henderson and Nataro, 2001; Yen et al., 2002). Recently, an intramolecular chaperone domain (also called autochaperone domain) has been identified in some autotransporters (Oliver et al., 2003b). This domain, as its name implies, is absolutely necessary for the correct folding of the BrkA passenger domain on the bacterial cell surface. However, at the moment it is not known whether the presence of this intramolecular chaperone is a feature universal to all autotransporters.

At the C-terminus, the translocation unit (also called helper domain, C-domain, transporter domain or, confusingly, autotransporter domain) is the last main domain (Figure 1A). This domain can be divided in two regions: (i) a short linker region having an $\alpha$-helical 


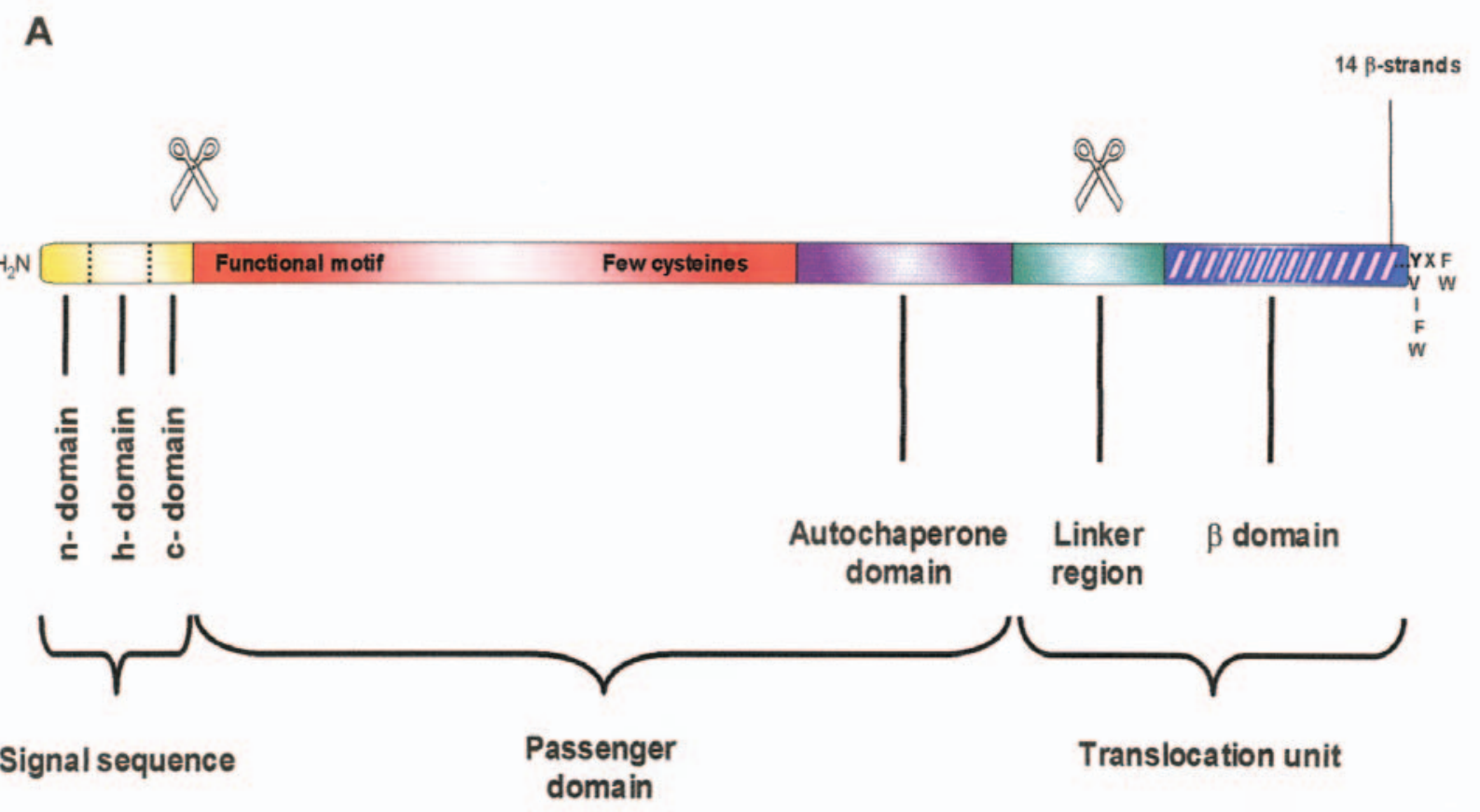

B

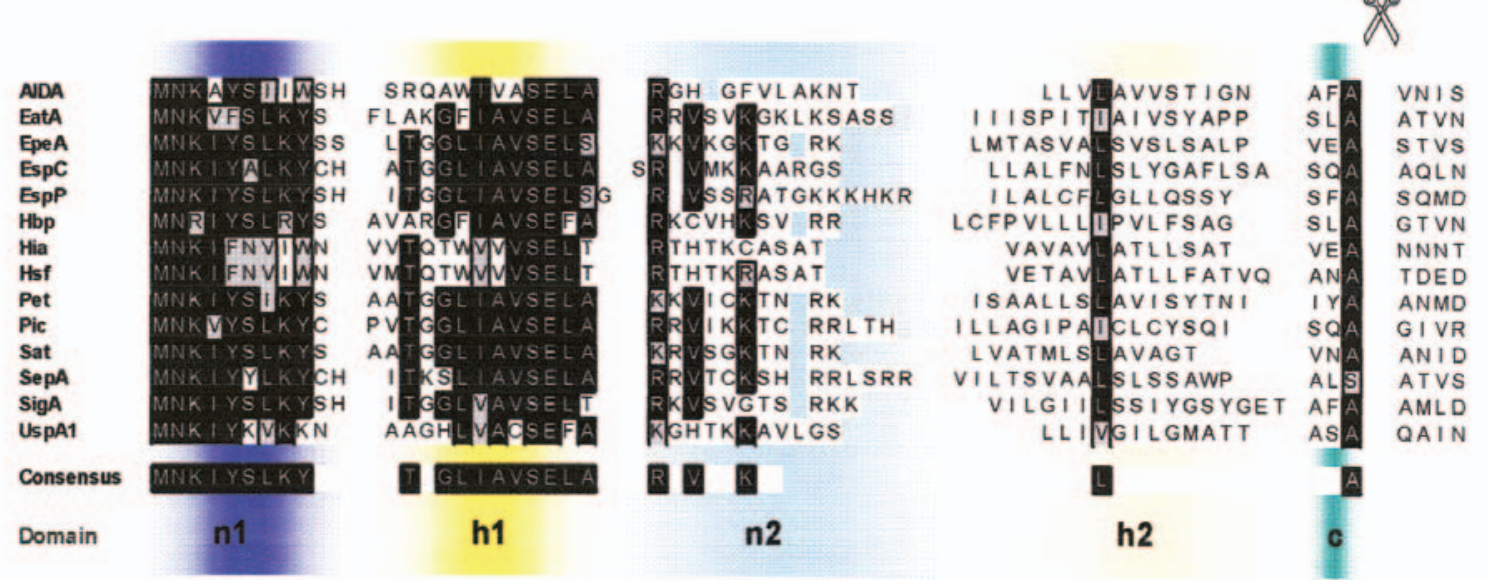

Figure 1. A: Primary structure of an autotransporter. Each of the major domains are depicted, and the scissors symbols denote the points of processing. B: Alignment of the amino-terminal segment of representative autotransporters possessing an extended signal sequence. The blue colour symbolises hydrophilic domains, i.e. the n1- and n2-domains. The yellow colour symbolises hydrophobic domains, i.e. h1- and h2-domains. The green colour symbolises the cdomain. Scissors symbolise the cleavage site.

secondary structure and, (ii) a $\beta$-domain (also called the $\beta$-core) that will adopt a $\beta$-barrel secondary structure when embedded in the outer membrane (Maurer et al., 1999). The translocation unit is the determinant for the secretion of the passenger domain across the outer membrane and a lot of research has focused on this region in the last few years.
The $\beta$-domain of autotransporters are all homologous (Yen et al., 2002). Two integral parameters generally permit classification of polypeptides as $\beta$-barrels (Schulz, 2003): (i) $n$, the number of strands in the $\beta$-sheets and, (ii) $S$, the shear number corresponding to the stagger of the strands in the $\beta$-sheet. $n$ and $S$ determine the major geometrical features of $\beta$-barrels, such as the mean slope of the strands 
A
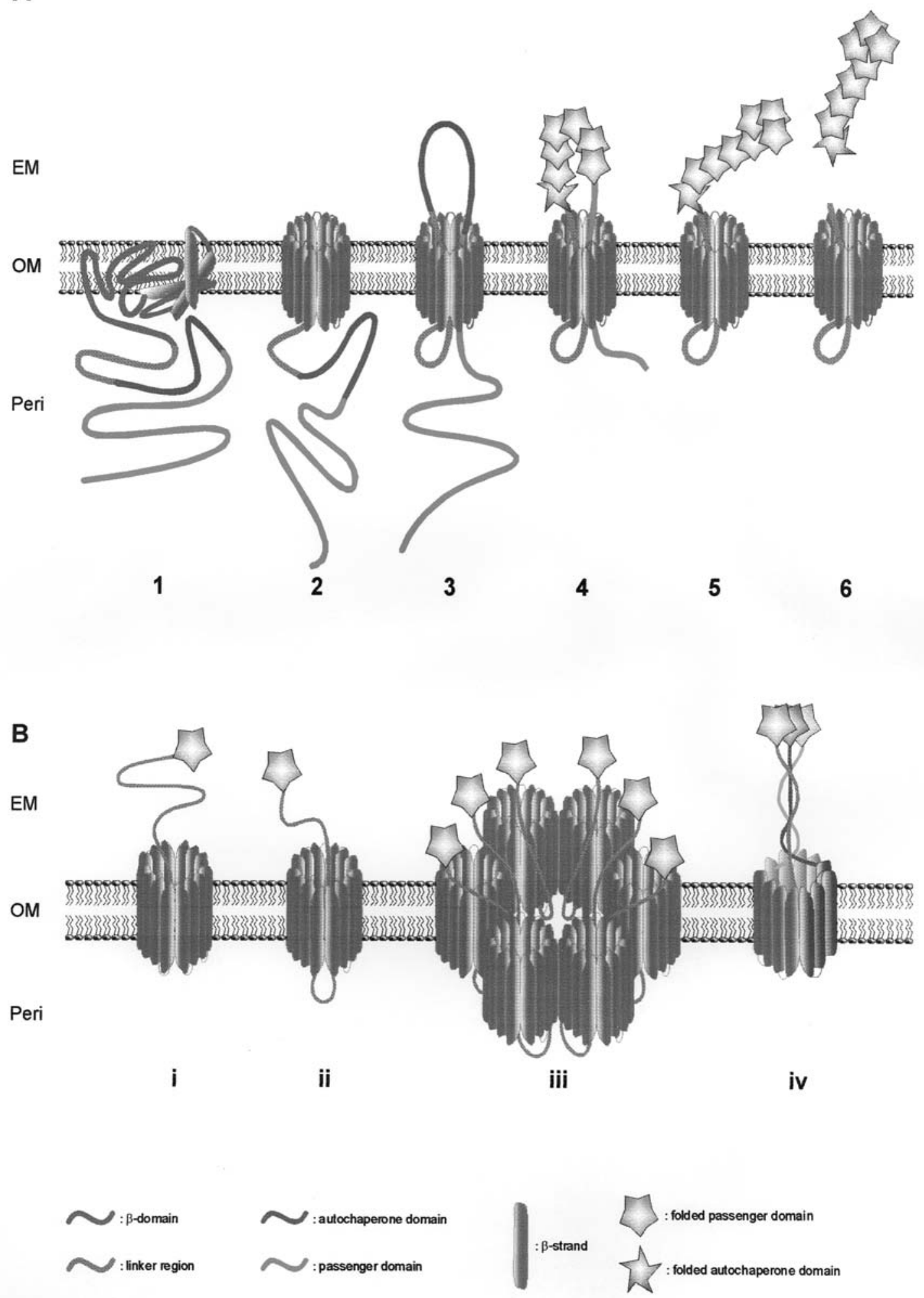

Figure 2. A: Updated model of the passenger domain secretion across the outer membrane. Steps 1 to 2 : insertion of the $\beta$-domain into the OM and folding in a $\beta$-barrel conformation. Steps 2 to 3 : initiation of secretion directed by the linker region through the pore formed by the monomeric $\beta$-barrel. Steps 3 to 4 : secretion and folding of the autochaperone domain which triggers the folding of the passenger domain as it emerges from the pore. Steps 5 to 6 : completion of the secretion and concomitant folding of the passenger domain followed by its release into the extracellular milieu. Peri : periplasm; OM : outer membrane; EM : extracellular milieu. B: Topology of the translocation unit in the outer membrane. $\mathrm{i}$ : model of direct folding and display of the passenger domain on the extracellular side of the OM. ii : model of secretion through the monomeric $\beta$-barrel. ii : model of oligomerisation of monomeric $\beta$-barrels and secretion through the central pore. iv : model of a TolC-like pore formation through trimerisation of translocation units and secretion through the central pore. Peri : periplasm; OM : outer membrane; EM : extracellular milieu. 
to the axis of the barrel, $\alpha$, and the mean radius of the barrel, $R$ (Murzin et al., 1994b, a). Due to the hydrogenbonding requirements along the whole $\beta$-strands, the sheets are also twisted and coiled. $\beta$-barrels can have different theoretical topologies, the simplest of those being the all-next-neighbour connection between adjacent strands. Actually, this is the conformation that has been found so far in all integral outer membrane proteins whose structures have been resolved (Delcour, 2002). As these parameters remain unavailable for autotransporters, the exact shape of the autotransporter $\beta$-barrels is still elusive and subject to speculation. However, using bioinformatic tools, it has been predicted that the $\beta$-domains of most autotransporters exhibit 14 antiparallel amphipathic strands consisting of 9 to 12 residues (Loveless and Saier, 1997; Yen et al., 2002). The $\beta$-domains share a consensus amino acid motif at the extreme carboxyl terminus, which represents the final spanning segment (Jose et al., 1995; Loveless and Saier, 1997). The terminal amino acid is always phenylalanine or tryptophan, preceded by alternating hydrophilic (charged or polar) and hydrophobic residues, i.e. (Y/V/I/F/W)-X-(F/ W).

\section{Inner membrane translocation pathways}

The issue of inner membrane targeting and translocation of the autotransporter proteins must in fact be placed in the context of the more general issue of protein export which to date is still not fully understood. In bacteria two inner membrane translocation systems have been described which allow protein export into the periplasmic space. On the one hand, the most recently discovered twin-arginine translocation (Tat) pathway is composed of the TatABCE translocon (Berks et al., 2000), while on the other the Sec (Secretion) system involves the SecYEG translocon (a protein conducting channel) and the cytoplasmic ATPase, SecA, which provides the energy for translocation (Driessen et al., 1998). However, two distinct protein targeting pathways converge at the Sec translocon: the SRP (Signal Recognition Particle)-dependent and the SecB-dependent pathways (Valent et al., 1998). It is worth mentioning that YidC, the Escherichia coli homologue of the yeast mitochondrial inner membrane protein (IMP) Oxa1p, is involved in both the Sec-translocase dependent and Sec-translocase-independent IMP assembly (de Gier and Luirink, 2001). This led some authors to classify the YidC pathway as a third inner membrane translocation system (Yen et al., 2002), yet to date YidC has not been implicated in the translocation of proteins across the inner membrane with their further release into the periplasmic space (Samuelson et al., 2000; Froderberg et al., 2003). A subject of controversy is the involvement of other molecular chaperones as targeting factors instead of SecB. While the possible involvement of other molecular chaperones has long been questioned (Mori and Ito, 2001; Muller et al., 2001) and some have even claimed that they cannot substitute for SecB function (Fekkes and Driessen, 1999), it is now clear that some proteins are routed to the Sec system via SecB- and SRP-independent pathways (Qi et al., 2002; Beha et al., 2003). Furthermore, SecB is not an essential cell component and should be considered as only one of the plethora of molecular chaperones available to a newly synthesized polypeptide before its export (Economou, 2002; Randall and Hardy, 2002). However, for the alternative chaperones, like GroEL, GroES or DnaK, the recognition mechanism permitting the targeting of the exported protein to the Sec translocon remains elusive. Nevertheless, taken all together these data show that the inner membrane translocation is more flexible and versatile than originally thought (Pugsley, 1993).

Thus, the first step in autotransporter protein secretion is the recognition and targeting of the cytoplasmic prepro-protein, with the help of a cleavable N-terminal signal sequence, to one of the inner membrane transport systems. Using SignalP (Nielsen et al., 1999), bioinformatic analyses revealed that the $\mathrm{N}$-terminal signal sequences of most autotransporters function as prototypical signal sequences of the SecB-dependent pathway (Henderson et al., 1998). In the SecB-dependent pathway, SecB binds to the mature part of the pre-protein. Actually, it has long been held that $\mathrm{SecB}$ functions primarily as a specific signal recognition factor by binding to the signal sequence of exported proteins (Watanabe and Blobel, 1989, 1995). However, further investigations have shown definitively that although SecB binds to the mature part of the pre-protein, the signal sequence provides no positive contribution to the binding energy or affinity of the interaction but it only slows the folding of the mature part (Randall et al., 1998). Thus the question arises of how SecB discriminates between cytoplasmic proteins and those to be exported. While the precise mechanism of this discrimination is still not fully understood, it is known that in addition to proteins exported via the Sec translocon, SecB acts as a molecular chaperone binding to non secreted proteins and some proteins secreted via the Type I protein system (Sapriel et al., 2003). Therefore, some kind of selectivity must govern the SecB targeting towards the Sec system. The slow folding rate of secretory proteins has long been assumed to be the basis for this discrimination, allowing the binding by the secretory chaperone, $\mathrm{SecB}$, and subsequent targeting to the translocase (Fekkes and Driessen, 1999). However, recent investigations suggest that while slow folding may be a necessary criterion for export, it is not sufficient and secreted proteins must contain information, in addition to the signal sequence and slow folding characteristics, that target them to the Sec pathway (Mallik et al., 2002). Nevertheless, it is now clearly established that SecB functions both as a targeting factor and as a molecular chaperone, keeping the precursor in a loosely folded conformation and conferring export competence.

Some autotransporters possess signal peptides containing around 50 amino acid residues which is unusually long compared to other SecB-dependent exported proteins (Figure 1B), but of a similar size to signal sequences of the Tat family. It is worth mentioning that aside from the autotransporter proteins such unusual signal sequences have only been observed in the TpsA and Oca family members of the type $\mathrm{V}$ secretion system (Henderson et al., 1998). All of these extended signal sequences consist of a MNKIYSLKY $(\mathrm{S} / \mathrm{C} / \mathrm{H})$ motif containing hydrophilic and positively charged residues, followed by a conserved motif with a succession of aromatic and hydrophobic residues mainly, i.e. GLIAVSELAR, immediately preceding the core $n$-domain. This sequence extension can either be 
described as an extended n-domain (Henderson et al., 1998; Sijbrandi et al., 2003) or perhaps more appropriately as a second signal sequence fused to the first one since two separate $\mathrm{n}$ - and $\mathrm{h}$-domains are present (Figure 1B). Thus, these extended signal sequences can be divided into five regions, which from the $\mathrm{N}$-terminus can be successively termed n1-, h1-, n2-, h2- and c-domains. The n2-domain is unusual in the number of basic amino acid residues that it contains, i.e. lysine, arginine and histidine (Brunder et al., 1997). For most of those autotransporter precursors, the h2-domain contains helix-breaking residues. While the extension constituted by the $\mathrm{n} 1$ - and $\mathrm{h} 1$-domains is highly conserved, the sequence of the n2-domain is variable and the following h2-domain even more so. It has been proposed that these conserved unusual features may impose additional properties such as recruiting other accessory proteins like SRP or by driving secretion through the inner membrane in a Sec-independent manner e.g. Tat (Fernandez and Weiss, 1994; Henderson et al., 1998).

While it has long been assumed that the Tat signal peptide motif was highly specific and conserved, recent investigations tend to temper such an assertion. In fact, it has been shown that substitution of one or both arginine residues by lysine could still permit targeting and translocation of the protein through the Tat translocon (Ize et al., 2002). Moreover, some proteins harbouring very distantly related twin arginine motifs, for example the penicillin amidase of Escherichia coli, which possess a signal sequence bearing two arginine residues separated by an asparagine residue, can nevertheless be routed towards the Tat pathway (Ignatova et al., 2002). Thus, involvement of the Tat pathway in the autotransporter secretion cannot be completely ruled out.

Controversy exists over whether the SRP-dependent pathway could be involved in the export of secreted proteins. While some results obtained from experiments with fusion proteins suggest that secretory proteins require SRP for export (Kim et al., 2001), it is generally assumed that secretory proteins of Gram-negative bacteria are not substrates of SRP. Certain polytopic membrane proteins of Escherichia coli are specifically and exclusively recognized by SRP for inner membrane integration (Koch et al., 1999; de Gier and Luirink, 2001). Therefore, SRP seems specific to IMPs and not involved in the export of secretory proteins (Beha et al., 2003). Interestingly, it has been reported that for some IMPs, while SRP was absolutely required for their translocation, the proteins were not delivered to the Sec translocase (Cristobal et al., 1999). While it has long been assumed that the insertion of IMPs into the inner membrane occurs spontaneously, it now appears that they all require the assistance of protein factors (Froderberg et al., 2003). IMP assembly can be (i) SRP dependent which does not rule out their SecB dependence and vice versa, (ii) SRP dependent but independent of the Sec translocase, i.e. SecAYEG, (iii) Sec translocase dependent but differing in their specific Sec-translocase requirements, suggesting a highly flexible translocation mechanism (Samuelson et al., 2000). Indeed, such flexibility is supported by a recent investigation of the $\mathrm{Hbp}$ autotransporter of Escherichia coli, which possesses the unusual extended signal sequence, which demonstrated that contrary to current opinion the targeting and translocation of this protein through the inner membrane involved the SRP-dependent pathway including the Sec translocon (Sijbrandi et al., 2003). The Tat translocon did not seem to be involved in secretion and $\mathrm{SecB}$ was apparently not required for targeting of $\mathrm{Hbp}$ to the Sec translocon, but it could compensate to some extent for the absence of functional SRP. In the SRP-dependent pathway, which in Escherichia coli involves the SRP homologue Ffh and the SRP receptor FtsY, as the signal peptide emerges from the ribosome it is first recognised by the targeting factor SRP, presumably by its NG-domain (Cleverley and Gierasch, 2002). As suggested by crystal structure analysis of the SRP, where an unusual RNAprotein interface has been described (Batey et al., 2000), it was speculated that directly or indirectly the extended part of the autotransporter signal sequence, and/or the h2domain, was important for the recognition by SRP. Once the SRP-nascent polypeptide complex is formed, SRP arrests translation, ensures that the nascent protein complex is delivered to the Sec translocon via interaction with the SRP-receptor and is subsequently released allowing the remainder of the protein to be translated such that translation and export are temporally coupled (von Heijne, 1998; Valent, 2001; Koch et al., 2003). In contrast to the SecB-dependent pathway, which permits posttranslational translocation of the protein, the co-translational export of the SRP pathway offers the advantage of preventing premature degradation or folding of the autotransporter protein in the cytoplasm. This is a particularly important feature when one considers that autotransporters range in size from 60-500 kDa. The secretion of the autotransporter $\mathrm{Hbp}$ represents the first ever example of secretion of an extracellular protein via an SRP-dependent pathway (Sijbrandi et al., 2003).

In contrast, another recent investigation with an autotransporter displaying the unusual extended signal sequence, i.e. EspP of enterohaemorrhagic Escherichia coli, revealed that contrary to $\mathrm{Hbp}$, only the SecB dependent pathway seemed to be involved in the secretion (Szabady and Bernstein, 2003). A similar conclusion was drawn from the study of the autotransporter IcsA of from Shigella flexneri (Brandon et al., 2003). For EspP, it appeared that the $\mathrm{N}$-terminal extension, i.e. the $\mathrm{n} 1$ - and $\mathrm{h} 1$-domains, could not act as a signal peptide by itself. When it was removed, the core signal peptide facilitated translocation across the inner membrane but seemed to prevent the further processing into the mature cleaved EspP, although it is generally assumed that the signal sequence has no further role after the initiation of the translocation event (Manting and Driessen, 2000). It is of general acceptance that once it has been cleaved by the peptidase, the fate of the signal sequence is to be digested into free amino acids by various peptidases. However, it has been speculated that a second function, distinct from the role of targeting, could be endorsed by release of this peptide (Martoglio and Dobberstein, 1998; von Heijne, 1998). In another recent study by Bernstein's group, it was shown that the fusion of $\Delta$ Esp, i.e. the truncated EspP signal sequence containing the n2- and h2- domains only, to proteins normally targeted to the Sec system by SecB leads to the rerouting of these proteins into the SRP pathway (Peterson et al., 2003). It was suggested that the basic amino acids in $\Delta \mathrm{Esp}$ contribute to eliminating the $\operatorname{Sec} B$ requirement and, more 
generally, that basic residues promote the binding of SRP to only a subset of signal peptides whose hydrophobicity falls slightly below a critical level. Such results seem apparently contradictory with previous finding (Szabady and Bernstein, 2003), however, in the latter study only $\Delta E s p$ was used and no data are available about the influence of the original signal sequence on the targeting of EspP or other proteins fused to it. In fact, it seems that the length, the net positive charge and number of hydrophobic amino acids in a targeting signal permit an exquisite degree of specificity and effectiveness for SRP recognition (Peterson et al., 2003). Further insight into the function of the unusual signal peptides in its full length is needed, particularly concerning the intriguing result suggesting the direct or indirect involvement of the signal peptide in the further processing of the mature autotransporter.

Once the pre-pro-protein has been targeted to a specific inner membrane translocon the signal sequence must be removed to release the autotransporter proprotein into the periplasm. Two types of leader peptidase are known to cleave the signal peptide: the type I serving ordinary pre-proteins and the type II for lipoproteins. The type I peptidase recognises the motif $S_{n} X S_{n}$, where $S_{n}$ stands for $\underline{S}$ mall neutral side chain residue and $X$ is highly variable. The $S_{n}$ residues are located at position -3 and -1 relative to the start of the mature protein and are either helix breaking amino acids, such as proline or glycine, or uncharged and/or short lateral chain residues, such as alanine, serine, threonine or valine. The motif recognised by the type II peptidase is $L_{h} X S_{n} C$ where $L_{h}$ stands for large hydrophobic residue and $C$ for cysteine. The amino acid in position +1 is always a cysteine while the $L_{h}$ residue in position -3 is preferentially a leucine. Several autotransporter lipoproteins, such as AspA from Nesseira meningitidis, AlpA from Helicobacter pylori or SphB1 from Bordetella pertussis, have been identified and characterised (Odenbreit et al., 1999; Coutte et al., 2001; Turner et al., 2002; Coutte et al., 2003; Masignani et al., 2003). However, while the involvement of a type II signal peptidase for the cleavage of those signal sequences can be assumed, to date no direct evidence is readily available for autotransporter lipoproteins.

\section{Outer membrane pore formation}

It has been suggested that after its export through the inner membrane, the autotransporter protein, or pro-protein, interacts with the hydrophobic environment of the outer membrane, which promotes its spontaneous insertion into the outer membrane and folds in a thermodynamically favoured $\beta$-barrel conformation before passenger domain translocation (Figure 2A) (Henderson et al., 1998). This model was originally based on the mechanism of porin biogenesis (Tamm et al., 2001). The insertion model proposes that as the unfolded protein approaches the outer membrane in an unstructured form, it forms a "molten-disc" intermediate which locates at the interface of the leaflets of the lipid bilayer and subsequently adopts an inside-out "molten-globule" form penetrating more deeply into the phosphoslipid bilayer to finally attain a well-defined native transmembrane structure (Tamm et al., 2001). These successive intermediates should not be considered as defined structures but rather as a large ensemble of structures characterized by common properties.

Until very recently it was still believed that even if chaperone proteins bind to unfolded outer membrane proteins to prevent their misfolding, the membrane insertion and concomitant folding and/or assembly reactions were a spontaneous thermodynamically-driven process which did not require any accessory protein (Tamm et al., 2001). This evidence is mostly derived from in vitro refolding experiments using the monomeric outer membrane protein OmpA as a model of $\beta$-barrel outer membrane proteins (OMP). Recently, this view has been changed by the first description of an assisted folding pathway for integral membrane proteins (Bulieris et al., 2003). Previous investigations performed with other transmembraneforming $\beta$-barrels have suggested that lipopolysaccharide (LPS) and periplasmic chaperone(s), such as Skp or SurA, might be important for the proper OMP assembly into the outer membrane (Freudl et al., 1986; Lazar and Kolter, 1996; de Cock et al., 1999). Using OmpA as an example Bulieris et al. (2003) recently proposed a model in which a small number of molecules of the periplasmic chaperone Skp bind to the OMP, maintaining it in a soluble unfolded state. This intermediate periplasmic complex then interacts with a small number of LPS molecules to form a folding competent intermediate. Finally, the folding competent OmpA inserts and folds into the lipid bilayer. Skp and LPS function as co-chaperones and seem to be involved in a general folding pathway of outer membrane proteins as suggested by (i) the binding of Skp to several OMPs, (ii) the lower expression levels of several OMPs following the deletion of the skp gene (Chen and Henning, 1996) and (iii) the report of specific LPS binding motifs in several OMPs (Ferguson et al., 2000). However, since deletion of the $s k p$ gene does not entirely eliminate the presence of OMPs in the outer membrane, but only decreases their concentration, it was also pointed out this Skp-LPS assisted folding pathway was certainly not the only mechanism by which OMPs insert and fold into the outer membrane. This assertion proved to be predictive as in the following months an even more decisive discovery was made, involving the surface antigen omp85, which radically challenged the idea of a spontaneous assembly of OMPs in the outer membrane (Voulhoux et al., 2003). Omp85 is a highly conserved protein since homologues are present in all the complete genome sequences of Gram-negative bacteria. Interestingly, the gene is located in close proximity to the skp gene and to the $I p \times A$ and $I p \times B$ genes involved in lipopolysaccharide biogenesis. This protein is essential for cell viability and for OMP assembly. Following Omp85 depletion it has been shown that unassembled forms of various outer membrane proteins, including autotransporters, accumulated. Thus Omp85 could possess a general function in the assembly of OMPs though the molecular mechanisms underlying this function remain to be elucidated. More recently, however, Genevrois et al. challenged this view by demonstrating that Omp85 was in fact involved in lipid export from the inner to the outer membrane (Genevrois et al., 2003). In this study, the localization of some OMPs was not impaired upon Omp85 depletion but degradation products were observed. Moreover, the isolation of an omp85 knockout mutant in a LPS-deficient mutant, which would have 
definitively demonstrated that Omp85 was only involved in the LPS transport, proved to be nearly impossible to obtain suggesting additional function(s) for Omp85. Also, a concerted mechanism where Omp85 permits phospholipid and LPS transport to and assembly in the outer membrane, as well as the assembly of OMPs, cannot be ruled out completely and necessitates further investigations.

In the case of PhoE, an Escherichia coli porin, substitution or deletion of the C-terminal phenylalanine has a drastic effect on protein folding and stabilization of the monomer resulting in an ineffective trimerization and outer membrane localization of the protein (Struyve et al., 1991; de Cock et al., 1997; Jansen et al., 2000). This observation has also been extended to the autotransporter proteins with the example of the autotransporter Hap from Haemophilus influenzae where deletion, but not mutation, of the three terminal amino acid residues has been shown to abolish outer membrane localization of the protein (Hendrixson et al., 1997). In addition, interaction with the periplasmic chaperone, Skp, has so far never been reported for autotransporters. The status of the autotransporter proteins in the periplasm is highly controversial, especially when considering how an unfolded or partially folded protein could be maintained and resist degradation by proteases present in the periplasmic space. It has been suggested that general or autotransporter specific chaperones could be involved, but few have been identified so far. However, in the case of the autotransporter IcsA, it has been shown that the periplasmic chaperone activity of DegP was involved (Purdy et al., 2002). For this autotransporter the periplasmic intermediate was also described as being transient suggesting that the translocation unit inserts rapidly into the outer membrane (Brandon and Goldberg, 2001).

\section{Secretion through the outer membrane}

The original model of outer membrane secretion predicts that the first of the $\beta$-strands passes from the periplasmic space to the external surface thus leaving the passenger domain temporarily extending into the periplasm (Henderson et al., 1998). The first and last $\beta$-sheets spontaneously form hydrogen bonds in an antiparallel fashion to close the ring conformation, permitting the establishment of a molecular pore. The alternating hydrophobic side chains of amino acids are embedded within the hydrophobic lipid bilayer while the hydrophilic side chains project into an aqueous environment in the centre of the barrel. Several topologies and associated secretion processes have been proposed throughout the literature (Figure 2B). The simplest hypothesis to explain the secretion of the passenger domain was the direct folding of the $\beta$-barrel in a conformation where the passenger domain was displayed in the extracellular milieu. In this model secretion would occur concomitantly with the folding of the $\beta$-domain (Figure $2 \mathrm{~B}$ ).

Originally, it was shown that outer membrane translocation was a two step process involving first the insertion of the $\mathrm{C}$-terminal $\beta$-domain into the outer membrane and then the translocation of the passenger domain (Klauser et al., 1990, 1992; Klauser et al., 1993a; Klauser et al., 1993b) (Figure 2B). In this model, the passenger domain is secreted through the hydrophilic channel formed anteriori by the monomeric $\beta$-barrel. From the seminal studies on the secretion of $\lg A 1$ protease, it appears that translocation across the outer membrane takes place in an unfolded or translocation competent conformation. It was thought that a globular conformation was not compatible with the translocation of the protein through the pore formed by the monomeric $\beta$-barrel. This view was corroborated by the fact that the formation of disulfide bonds in the passenger domain, effected by the major periplasmic disulfide bond forming enzyme DsbA, reduced the efficiency of secretion of the passenger domain (Jose et al., 1996). This also suggested that the pro-protein (or protein) was accessible to periplasmic enzymes and that at least partial folding of the autotransporter arises in the periplasm. However, the paucity of cysteine residues is also a unifying characteristic of autotransporter passenger domain (Jose et al., 1995). It was then predicted that some mechanisms exist to maintain the protein in a translocation compliant state and to promote proper folding of the passenger domain on the surface of the bacterium. This point stressed that the issues of the folding of the passenger domain, the topology of the $\beta$-barrel and the secretion of the passenger domain are intimately linked and cannot easily be dissociated. The existence of an ion channel was demonstrated for the first time with the $\mathrm{C}$-terminal domain of the autotransporter BrkA of Bordetella pertussis which displayed an average conductance of $3.0 \mathrm{nS}$ in $1 \mathrm{M} \mathrm{KCl}$ (Shannon and Fernandez, 1999). It was recently argued that in this study, the channel could not have been present in a native state since the $\beta$-barrel of BrkA was refolded in vitro after its solubilisation from inclusion bodies (Veiga et al., 2002). Further investigations challenged the view of an unfolded conformation being required for passenger domain secretion. By using a single-chain antibody as a reporter passenger domain, it was concluded that the folding of the passenger domain takes place in the periplasm before, or at least simultaneously, with its own translocation through the outer membrane (Veiga et al., 1999). Moreover, using IcsA as an example, it was demonstrated that the presence or absence of DsbA does not make any difference in the stability and targeting of the passenger domain to the outer membrane, even if reduction of the disulfide bridges allowed a more efficient secretion of the passenger domain (Valls et al., 2000; Brandon and Goldberg, 2001).

The contradictory results of these previous investigations with the original model raised the question of how a folded polypeptide could be translocated through the somewhat narrow hydrophilic channel of a monomeric $\beta$-barrel (Nikaido, 1992, 1994). On the basis of a reinvestigation of the $\lg A 1$ protease secretion, an alternative secretion model has recently been proposed. This model suggests that instead of secretion through a pore formed by one monomeric $\beta$-barrel, secretion would occur through an oligomeric ring-shaped structure consisting of a minimum of $6 \beta$-barrels forming a central pore of about $2 \mathrm{~nm}$ diameter (Veiga et al., 2002) (Figure 2B). This structure seemed similar to that of outer membrane complexes found in some other secretion systems, e.g. secretin or fimbrial ushers (Thanassi, 2002). This pore was supposed to be large enough to tolerate the passage of protein in a folded state. Still, the exact 
structure of this oligomeric ring remains speculative since it was proposed that the oligomeric ring could also consist of 8-10 monomers. This study contradicts earlier findings, made with the Escherichia coli autotransporter Antigen 43 , in which passenger-domain/passenger-domain and passenger-domain/ $\beta$-domain interactions could be detected by cross-linking experiments, but in which no $\beta$-domain/ $\beta$ domain interactions were detected (Owen et al., 1996). It is worth mentioning here that the initial characterisation of this oligomeric ring-shaped structure was performed in vitro using the C-terminal part of the truncated IgA1 $\beta$-domain. $\lg A 1$ is the only autotransporter for which such quaternary structural organisation of the $\beta$-barrels has been proposed so far. This model raises several questions, notably how the pore formed by this oligomeric ring could be hydrophilic if we consider that the outside of the individual $\beta$-barrels are predicted to be mostly hydrophobic and, if so, how could it permit the efficient translocation of a hydrophilic passenger domain. A channel of this size, however, cannot permit the secretion of large folded passenger domains such as a nonreduced single chain antibody (Veiga et al., 1999; Oliver et al., 2003b). Experimental evidence of passenger domain secretion through the common oligomeric ring-shaped channel is still lacking. Nevertheless, such an oligomeric organisation remains compatible with either the secretion of the passenger domain in an unfolded or partially folded state or a secretion process occurring through individual monomeric $\beta$-barrels as originally proposed. It is therefore too early to establish this structure and secretion model as a general feature of all autotransporters. The controversy around the topology of the $\beta$-barrel of autotransporters should hopefully be resolved in the near future through efforts being made by several research teams to crystallize the translocation unit.

In addition to the $\beta$-domain, a very important and essential domain for secretion of the passenger domain is the linker region found upstream of the $\beta$-core, which together form the translocation unit (Miyazaki et al., 1989; Maurer et al., 1999; Oliver et al., 2003a,b). While the size of the translocation unit can be quite variable among autotransporters (between 30 and $60 \mathrm{kDa}$ ) the size of the $\beta$-core is remarkably similar (Oliver et al., 2003a). It has been proposed that the linker region, consisting of a 21 to 39 -amino acid $\alpha$-helical region preceding the $\beta$-core, is involved in forming a hairpin structure that leads secretion of the passenger domain through the channel formed by the $\beta$-barrel (Henderson et al., 1998).

From the study of the autotransporter PrtS from Serratia marcescens, it was demonstrated that the folding of the passenger domain only occurs on the bacterial cell surface and implied a putative intramolecular chaperone region (Ohnishi et al., 1994). A recent investigation has definitively revealed the presence of an intramolecular chaperone, the PD002475 domain, in several autotransporters including BrkA, IgA1 and IcsA (Oliver et al., 2003b). This well conserved domain is found upstream of the translocation unit. It was demonstrated that this domain is important for the folding of the BrkA passenger domain, probably by triggering or initiating correct folding of the passenger domain. In BrkA, this domain could act as an intramolecular building block by scaffolding the folding of any protein linked to it (Ma et al., 2000). This autochaperone domain is cleaved from the passenger domain of PrtS but not from BrkA suggesting that the folding mechanism(s) may differ depending on the autotransporter (Oliver et al., 2003b). In PrtS, however, a PD002475 domain was not found suggesting that the junction domain probably corresponds to a distinct type of endochaperone. From this study, the model proposed for transport of the autotransporter to the surface was that the passenger domain remains unfolded, or partially folded, as it transits through the channel. Folding is triggered by the autochaperone domain and begins vectorially in a C-terminal direction on the bacterial surface as the passenger domain emerges from the $\beta$-domain channel (Figure 2A). The complete folding of the protein then occurs on the surface of the bacteria, suggesting that previous findings were probably biased by the study of a passenger domain unrelated to the autotransporters (Veiga et al., 1999).

Concerning the energy used to translocate proteins across the bacterial outer membrane it has long been speculated that translocation across both membranes could be coupled and the free energy of folding might be the driving force for translocation. In fact, since ATP or GTP hydrolysis has never been reported to occur in the periplasm and that there is no evidence for the existence of a proton motive force $(\Delta p)$ across the outer membrane, those possibilities have never been considered as a driving force for translocation of the passenger domain through the outer membrane. However, from the study of Veiga et al. (1999) it appeared unlikely that the energy required for translocation through the outer membrane would be provided by the self-folding of the passenger domain in the extracellular environment. But since this set of experiments used a non-native passenger domain lacking the intramolecular chaperone domain, a common sorting mechanism assisting the assembly and export of autotransporter proteins that could involve the autochaperone domain cannot be ruled out.

Cleavage between the passenger domain and the translocation unit of the pro-protein can occur on the bacterial surface either well upstream of the linker region or within the predicted $\alpha$-helical region (Oliver et al., 2003a). In some cases, the passenger domain remains steadfastly associated with the bacterial surface via a noncovalent interaction with the $\beta$-domain and possibly with the linker region which could act as an anchor for the passenger domain (Li et al., 1991; Benz and Schmidt, 1992; Owen et al., 1996). The passenger domain is not necessarily cleaved but can also remain intact as a large protein with a membrane-bound carboxyl-terminal domain and an amino-terminal domain extending into the extracellular milieu (St Geme and Cutter, 2000). In those cases where cleavage occurs, controversy still exists over whether the cleavage is a result of a membrane bound protease or an autoproteolytic event. For some autotransporters, it has been demonstrated that cleavage was the result of an autocatalytic event involving a serine protease active site present in the passenger domain of the autotransporter (Serruto et al., 2003). The passenger domains may also be processed at several sites and possibly by a variety of proteases (Hendrixson et al., 1997). Some autotransporters have been shown to undergo processing even after deletion of their serine protease motif suggesting the action of 
alternative proteases (Benjelloun-Touimi et al., 1995). For IcsA, it has been demonstrated that cleavage was the result of another membrane protease called IcsP (Shere et al., 1997).

Interestingly, IcsA has the unusual characteristic of being localized at a single pole of the bacillus (Goldberg et al., 1993). The current model suggests that, upon translocation into the outer membrane at one pole of the bacillus, IcsA, which is anchored in the membrane by its $\beta$-domain, diffuses laterally within the outer membrane towards the septum (Steinhauer et al., 1999). IcsP, which is localized in the outer membrane, slowly cleaves IcsA at all sites on the bacterial surface, but as the insertion of IcsA is occurring exclusively at one pole it results in an unipolar distribution of IcsA (Steinhauer et al., 1999). Since the localization of IcsA is independent of the signal sequence, it has been also proposed that IcsA targeting and secretion across the inner membrane occurs only at one pole (Charles et al., 2001). It was suggested that the $\mathrm{N}$-terminal region of IcsA, including the signal sequence, could interact with an unknown structure at the pole (Brandon et al., 2003). These models have, however, been revised recently since this apparent polar localisation was partly due to the masking of IcsA by lipopolysaccharide (LPS) O-antigen side chains (Oag) (Morona and Van Den Bosch, 2003). Although IcsA is predominantly exported to one cell pole export also occurs at the lateral region of the cell but is not detected due to the presence LPS Oag chains.

\section{Outer membrane translocation in related systems}

In the bacterial two-partner system (TPS) or type $V_{b}$ secretion pathway (Desvaux et al., 2003), the passenger domain TpsA also inserts into an outer membrane pore formed by a $\beta$-barrel of TpsB (Jacob-Dubuisson et al., 2001). Compared to the autotransporter proteins, the $\beta$-barrel topology is different as indicated by the prediction of 19 amphipathic $\beta$-strands in TpsB, instead of 14 for the autotransporter $\beta$-domain (Guedin et al., 2000) Furthermore, these systems produce different conductance values in $1 \mathrm{M} \mathrm{KCl}$ (Jacob-Dubuisson et al., 1999). In addition, TPS possesses additional levels of complexity, as suggested by the involvement of TpsB in the maturation of the passenger domain into its active form (Jacob-Dubuisson et al., 2001) or by the presence of C-terminal extensions in TpsA (Renauld-Mongenie et al., 1996). The TPS implies specific recognition events between the passenger domain and the transporter domain that involves, beyond the signal peptide, a secretion domain harbouring a conserved motif (Schonherr et al., 1993; Jacob-Dubuisson et al., 1997; Grass and St Geme, 2000). The TPS has an apparent lack of versatility since each TpsB transporter appears to be devoted essentially to the secretion of one exoprotein (Jacob-Dubuisson et al., 2001). It is suggested that the exoprotein transits the periplasm in an unfolded conformation and folds progressively at the cell surface after it is translocated through the transporter domain (Guedin et al., 1998). Thus, translocation across both membranes seems coupled and the free energy of folding might be the driving force for outer membrane translocation (Jacob-Dubuisson et al., 2001). Several passenger domains undergo further proteolytic processing concomitantly with secretion. The efficient extracellular release of the mature filamentous haemagglutinin (FHA) of Bordetella pertussis depends on the presence of a C-terminal domain in FhaB, which is proteolytically removed in the course of secretion. As observed in some autotransporters, this domain acts as an intramolecular chaperone to assist secretion by preventing premature folding (Renauld-Mongenie et al., 1996). Interestingly, it has been demonstrated that the Bordetella pertussis autotransporter SphB1 acted as a specific protease responsible for the bacterial surface maturation of FhaB, the filamentous haemagglutinin (FHA) secreted by the TPS (Coutte et al., 2001; Coutte et al., 2003).

More recently, the members of the Oca family have been described as a subfamily of surface-attached oligomeric autotransporters, with the example of YadA as a prototype (Roggenkamp et al., 2003). YadA possesses the three main domains of autotransporter, i.e. N-terminal signal sequence, passenger domain and translocation unit, but with the peculiarity that the $\mathrm{C}$-terminal region consists of only four $\beta$-strands. Deletion of the C-terminal domain abolished membrane insertion of YadA (Tamm et al., 1993) while the deletion of the linker region resulted in the degradation of the whole protein (Roggenkamp et al., 2003). This region forms a $\beta$-barrel pore consisting of 12 $\beta$-strands after trimerisation and confers an overall lollipoplike structure on the proteins displayed on the cell surface (Hoiczyk et al., 2000). TolC possesses an analogous $\beta$ barrel structure, though it also possesses $\alpha$-helical regions which extend into the periplasmic space (Koronakis et al., 2000). This conformation suggests an additional putative topology for the type $\mathrm{V}$ secretion systems (Figure 2).

\section{Concluding remarks}

The type $V$ secretion pathway could be briefly defined as the secretion of proteins that are translocated across the outer membrane via a transmembrane pore, formed by a $\beta$-barrel, and that contain all the information required for translocation of an effector molecule through the cell envelope (Henderson et al., 1998). Three different subgroups of secretion system fulfilling this definition have been described in the literature: the autotransporters, the TPS and the Oca family, also called respectively type $V_{a}$, $V_{b}$ and $V_{c}$ secretion system (Desvaux et al., 2003). The autotransporters are most certainly the subgroup which have attracted most interest in the last decade. Although the original secretion model proposed by Pohlner et al. (1987) at first appears quite simplistic, an in-depth analysis of the secretion processes reveals that much remains to be learned about the translocation steps through the inner and outer membranes. These questions have to be placed in the context of more general issues of protein translocation in bacteria. Future discoveries in the secretion process of the autotransporters, the TPS and the Oca family will certainly bring mutual benefits and a better understanding of these respective pathways of type $\mathrm{V}$ secretion. 


\section{Acknowledgements}

Work in our laboratory is supported by Biotechnology and Biological Sciences Research Council (BBSRC) grants 81/D14955 and 81/P14130 to IH.

\section{References}

Andersen, C. (2003). Channel-tunnels, outer membrane components of type I secretion systems and multidrug efflux pumps of Gram-negative bacteria. Rev. Physiol. Biochem. Pharmacol. 147, 122-165.

Batey, R.T., Rambo, R.P., Lucast, L., Rha, B. and Doudna, J.A. (2000). Crystal structure of the ribonucleoprotein core of the signal recognition particle. Science. 287, 1232-1239.

Beha, D., Deitermann, S., Muller, M. and Koch, H.G. 2003. Export of $\beta$-lactamase is independent of the signal recognition particle. J. Biol. Chem. 278, 22161-22167.

Benjelloun-Touimi, Z., Sansonetti, P.J. and Parsot, C. (1995). SepA, the major extracellular protein of Shigella flexneri, autonomous secretion and involvement in tissue invasion. Mol. Microbiol. 17, 123-135.

Benz, I. and Schmidt, M.A. (1992). AIDA-I, the adhesin involved in diffuse adherence of the diarrhoeagenic Escherichia coli strain $2787(\mathrm{O} 126: \mathrm{H} 27)$, is synthesized via a precursor molecule. Mol. Microbiol. 6, 1539-1546.

Berks, B.C., Sargent, F. and Palmer, T. $(2000)$. The Tat protein export pathway. Mol. Microbiol. 35, 260-274.

Blocker, A., Komoriya, K. and Aizawa, S. (2003). Type III secretion systems and bacterial flagella, insights into their function from structural similarities. Proc. Natl. Acad. Sci. U S A. 100, 3027-3030.

Brandon, L.D., Goehring, N., Janakiraman, A., Yan, A.W., Wu, T., Beckwith, J. and Goldberg, M.B. (2003). IcsA, a polarly localized autotransporter with an atypical signal peptide, uses the Sec apparatus for secretion, although the Sec apparatus is circumferentially distributed. Mol Microbiol. 50, 45-60.

Brandon, L.D. and Goldberg, M.B. (2001). Periplasmic transit and disulfide bond formation of the autotransported Shigella protein IcsA. J. Bacteriol. 183, 951-958.

Brunder, W., Schmidt, H. and Karch, H. (1997). EspP, a novel extracellular serine protease of enterohaemorrhagic Escherichia coli O157:H7 cleaves human coagulation factor V. Mol. Microbiol. 24, 767-778.

Bulieris, P.V., Behrens, S., Holst, O. and Kleinschmidt, J.H. (2003). Folding and insertion of the outer membrane protein OmpA is assisted by the chaperone Skp and by lipopolysaccharide. J. Biol. Chem. 278, 9092-9099.

Buttner, D. and Bonas, U. (2002). Port of entry, the type III secretion translocon. Trends Microbiol. 10, 186-192.

Charles, M., Perez, M., Kobil, J.H. and Goldberg, M.B. (2001). Polar targeting of Shigella virulence factor IcsA in Enterobacteriacae and Vibrio. Proc. Natl. Acad. Sci. U S A. 98, 9871-9876.

Chen, R. and Henning, U. (1996). A periplasmic protein (Skp) of Escherichia coli selectively binds a class of outer membrane proteins. Mol. Microbiol. 19, 1287-1294.

Christie, P.J. (2001). Type IV secretion, intercellular transfer of macromolecules by systems ancestrally related to conjugation machines. Mol. Microbiol. 40, 294-305.
Christie, P.J. and Vogel, J.P. (2000). Bacterial type IV secretion, conjugation systems adapted to deliver effector molecules to host cells. Trends Microbiol. 8, 354-360.

Cleverley, R.M. and Gierasch, L.M. (2002). Mapping the signal sequence-binding site on SRP reveals a significant role for the NG domain. J. Biol. Chem. 277, 46763-46768.

Coutte, L., Antoine, R., Drobecq, H., Locht, C. and JacobDubuisson, F. (2001). Subtilisin-like autotransporter serves as maturation protease in a bacterial secretion pathway. EMBO J. 20, 5040-5048.

Coutte, L., Willery, E., Antoine, R., Drobecq, H., Locht, C. and Jacob-Dubuisson, F. (2003). Surface anchoring of bacterial subtilisin important for maturation function. Mol. Microbiol. 49, 529-539.

Cristobal, S., Scotti, P., Luirink, J., von Heijne, G. and de Gier, J.W. (1999). The signal recognition particletargeting pathway does not necessarily deliver proteins to the sec-translocase in Escherichia coli. J. Biol. Chem. 274, 20068-20070.

Danchin, A. (2003). Genomes and evolution. Curr. Issues Mol. Biol. 5, 37-42.

de Cock, H., Brandenburg, K., Wiese, A., Holst, O. and Seydel, U. (1999). Non-lamellar structure and negative charges of lipopolysaccharides required for efficient folding of outer membrane protein PhoE of Escherichia coli. J. Biol. Chem. 274, 5114-5119.

de Cock, H., Struyve, M., Kleerebezem, M., van der Krift, T. and Tommassen, J. (1997). Role of the carboxy-terminal phenylalanine in the biogenesis of outer membrane protein PhoE of Escherichia coli K-12. J. Mol. Biol. 269, 473-478.

de Gier, J.W. and Luirink, J. (2001). Biogenesis of inner membrane proteins in Escherichia coli. Mol. Microbiol. 40, 314-322.

Delcour, A.H. (2002). Structure and function of pore-forming beta-barrels from bacteria. J Mol Microbiol. Biotechnol. 4, 1-10.

Desvaux, M., Parham, N.J. and Henderson, I.R. (2003). Le système de sécrétion de type $V$ chez les bactéries Gram-négatives. Biofutur. 237, 34-37.

Domenighini, M., Relman, D., Capiau, C., Falkow, S., Prugnola, A., Scarlato, V. and Rappuoli, R. (1990). Genetic characterization of Bordetella pertussis filamentous haemagglutinin, a protein processed from an unusually large precursor. Mol. Microbiol. 4, 787-800.

Driessen, A.J., Fekkes, P. and van der Wolk, J.P. (1998). The Sec system. Curr. Opin. Microbiol. 1, 216-222.

Economou, A. (2002). Bacterial secretome, the assembly manual and operating instructions. Mol. Membr. Biol. 19, 159-169.

Fekkes, P. and Driessen, A.J. (1999). Protein targeting to the bacterial cytoplasmic membrane. Microbiol. Mol. Biol. Rev. 63, 161-173.

Ferguson, A.D., Welte, W., Hofmann, E., Lindner, B., Holst, O., Coulton, J.W. and Diederichs, K. (2000). A conserved structural motif for lipopolysaccharide recognition by procaryotic and eucaryotic proteins. Structure Fold Des. 8, 585-592.

Fernandez, R.C. and Weiss, A.A. (1994). Cloning and sequencing of a Bordetella pertussis serum resistance locus. Infec.t Immun. 62, 4727-4738. 
Freudl, R., Schwarz, H., Stierhof, Y.D., Gamon, K., Hindennach, I. and Henning, U. (1986). An outer membrane protein (OmpA) of Escherichia coli K-12 undergoes a conformational change during export. J. Biol. Chem. 261, 11355-11361.

Froderberg, L., Houben, E., Samuelson, J.C., Chen, M., Park, S.K., Phillips, G.J., Dalbey, R., Luirink, J. and De Gier, J.W. (2003). Versatility of inner membrane protein biogenesis in Escherichia coli. Mol. Microbiol. 47, 10151027.

Genevrois, S., Steeghs, L., Roholl, P., Letesson, J.J. and van der Ley, P. (2003). The Omp85 protein of Neisseria meningitidis is required for lipid export to the outer membrane. EMBO J. 22, 1780-1789.

Goldberg, M.B., Barzu, O., Parsot, C. and Sansonetti, P.J. (1993). Unipolar localization and ATPase activity of IcsA, a Shigella flexneri protein involved in intracellular movement. J. Bacteriol. 175, 2189-2196.

Grass, S. and St Geme, J.W., 3rd. (2000). Maturation and secretion of the non-typable Haemophilus influenzae HMW1 adhesin, roles of the $\mathrm{N}$-terminal and C-terminal domains. Mol. Microbiol. 36, 55-67.

Guedin, S., Willery, E., Locht, C. and Jacob-Dubuisson, F. (1998). Evidence that a globular conformation is not compatible with FhaC-mediated secretion of the Bordetella pertussis filamentous haemagglutinin. Mol. Microbiol. 29, 763-774.

Guedin, S., Willery, E., Tommassen, J., Fort, E., Drobecq, H., Locht, C. and Jacob-Dubuisson, F. (2000). Novel topological features of $\mathrm{FhaC}$, the outer membrane transporter involved in the secretion of the Bordetella pertussis filamentous hemagglutinin. J. Biol. Chem. 275, 30202-30210.

Henderson, I.R., Cappello, R. and Nataro, J.P. (2000a). Autotransporter proteins, evolution and redefining protein secretion. Trends Microbiol. 8, 529-532.

Henderson, I.R., Cappello, R. and Nataro, J.P. (2000b). Autotransporter proteins, evolution and redefining protein secretion, response. Trends Microbiol. 8, 534-535.

Henderson, I.R. and Nataro, J.P. (2001). Virulence functions of autotransporter proteins. Infect. Immun. 69, 1231-1243.

Henderson, I.R., Nataro, J.P., Kaper, J.B., Meyer, T.F., Farrand, S.K., Burns, D.L., Finlay, B.B. and St Geme, J.W., 3rd. (2000c). Renaming protein secretion in the Gram-negative bacteria. Trends Microbiol. 8, 352.

Henderson, I.R., Navarro-Garcia, F. and Nataro, J.P. (1998). The great escape, structure and function of the autotransporter proteins. Trends Microbiol. 6, 370-378.

Hendrixson, D.R., de la Morena, M.L., Stathopoulos, C. and St Geme, J.W., 3rd. (1997). Structural determinants of processing and secretion of the Haemophilus influenzae Hap protein. Mol. Microbiol. 26, 505-518.

Hoiczyk, E., Roggenkamp, A., Reichenbecher, M., Lupas, A. and Heesemann, J. (2000). Structure and sequence analysis of Yersinia YadA and Moraxella UspAs reveal a novel class of adhesins. EMBO J. 19, 5989-5999.

Ignatova, Z., Hornle, C., Nurk, A. and Kasche, V. (2002). Unusual signal peptide directs penicillin amidase from Escherichia coli to the Tat translocation machinery. Biochem. Biophys. Res. Commun. 291, 146-149.

Ize, B., Gerard, F. and Wu, L.F. (2002). In vivo assessment of the Tat signal peptide specificity in Escherichia coli. Arch. Microbiol. 178, 548-553.

Jacob-Dubuisson, F., Antoine, R. and Locht, C. (2000). Autotransporter proteins, evolution and redefining protein secretion, response. Trends Microbiol. 8, 533-534.

Jacob-Dubuisson, F., Buisine, C., Willery, E., RenauldMongenie, G. and Locht, C. (1997). Lack of functional complementation between Bordetella pertussis filamentous hemagglutinin and Proteus mirabilis HpmA hemolysin secretion machineries. J. Bacteriol. 179, 775783.

Jacob-Dubuisson, F., El-Hamel, C., Saint, N., Guedin, S., Willery, E., Molle, G. and Locht, C. (1999). Channel formation by FhaC, the outer membrane protein involved in the secretion of the Bordetella pertussis filamentous hemagglutinin. J. Biol. Chem. 274, 37731-37735.

Jacob-Dubuisson, F., Locht, C. and Antoine, R. (2001). Two-partner secretion in Gram-negative bacteria, a thrifty, specific pathway for large virulence proteins. Mol. Microbiol. 40, 306-313.

Jansen, C., Heutink, M., Tommassen, J. and de Cock, H. (2000). The assembly pathway of outer membrane protein PhoE of Escherichia coli. Eur. J. Biochem. 267, 3792-3800

Jose, J., Jahnig, F. and Meyer, T.F. (1995). Common structural features of IgA1 protease-like outer membrane protein autotransporters. Mol. Microbiol. 18, 378-380.

Jose, J., Kramer, J., Klauser, T., Pohlner, J. and Meyer, T.F. (1996). Absence of periplasmic DsbA oxidoreductase facilitates export of cysteine-containing passenger proteins to the Escherichia coli cell surface via the Iga beta autotransporter pathway. Gene. 178, 107-110.

Kim, J., Rusch, S., Luirink, J. and Kendall, D.A. (2001). Is Ffh required for export of secretory proteins? FEBS Lett. 505, 245-248.

Klauser, T., Kramer, J., Otzelberger, K., Pohlner, J. and Meyer, T.F. (1993a). Characterization of the Neisseria Iga $\beta$-core. The essential unit for outer membrane targeting and extracellular protein secretion. J. Mol. Biol. 234, 579-593.

Klauser, T., Pohlner, J. and Meyer, T.F. (1990). Extracellular transport of cholera toxin B subunit using Neisseria IgA protease $\beta$-domain, conformation-dependent outer membrane translocation. EMBO J. 9, 1991-1999.

Klauser, T., Pohlner, J. and Meyer, T.F. (1992). Selective extracellular release of cholera toxin $B$ subunit by Escherichia coli, dissection of Neisseria Iga $\beta$-mediated outer membrane transport. EMBO J. 11, 2327-2335.

Klauser, T., Pohlner, J. and Meyer, T.F. (1993b). The secretion pathway of IgA protease-type proteins in Gramnegative bacteria. Bioessays. 15, 799-805.

Koch, H.G., Hengelage, T., Neumann-Haefelin, C., MacFarlane, J., Hoffschulte, H.K., Schimz, K.L., Mechler, B. and Muller, M. (1999). In vitro studies with purified components reveal signal recognition particle (SRP) and SecA/SecB as constituents of two independent proteintargeting pathways of Escherichia coli. Mol. Biol. Cell. 10, 2163-2173.

Koch, H.G., Moser, M. and Muller, M. (2003). Signal recognition particle-dependent protein targeting, universal to all kingdoms of life. Rev. Physiol. Biochem. Pharmacol. $146,55-94$. 
Koronakis, V., Sharff, A., Koronakis, E., Luisi, B. and Hughes, C. (2000). Crystal structure of the bacterial membrane protein TolC central to multidrug efflux and protein export. Nature. 405, 914-919.

Lazar, S.W. and Kolter, R. (1996). SurA assists the folding of Escherichia coli outer membrane proteins. J Bacteriol. 178, 1770-1773.

Li, L.J., Dougan, G., Novotny, P. and Charles, I.G. (1991). P.70 pertactin, an outer-membrane protein from Bordetella parapertussis, cloning, nucleotide sequence and surface expression in Escherichia coli. Mol. Microbiol. 5, 409-417.

Loveless, B.J. and Saier, M.H., Jr. (1997). A novel family of channel-forming, autotransporting, bacterial virulence factors. Mol. Membr. Biol. 14, 113-123.

Ma, B., Tsai, C.J. and Nussinov, R. (2000). Binding and folding, in search of intramolecular chaperone-like building block fragments. Protein Eng. 13, 617-627.

Mallik, I., Smith, M.A. and Flower, A.M. (2002). Recognition of secretory proteins in Escherichia coli requires signals in addition to the signal sequence and slow folding. BMC Microbiol. 2, 32.

Manting, E.H. and Driessen, A.J. (2000). Escherichia coli translocase, the unravelling of a molecular machine. Mol. Microbiol. 37, 226-238.

Martoglio, B. and Dobberstein, B. (1998). Signal sequences, more than just greasy peptides. Trends Cell Biol. 8, 410-415.

Masignani, V., Comanducci, M., Giuliani, M.M., Bambini, S., Adu-Bobie, J., Arico, B., Brunelli, B., Pieri, A., Santini, L., Savino, S., Serruto, D., Litt, D., Kroll, S., Welsch, J.A., Granoff, D.M., Rappuoli, R. and Pizza, M. (2003). Vaccination against Neisseria meningitidis using three variants of the lipoprotein GNA1870. J. Exp. Med. 197, 789-799.

Maurer, J., Jose, J. and Meyer, T.F. (1999). Characterization of the essential transport function of the AIDA-I autotransporter and evidence supporting structural predictions. J. Bacteriol. 181, 7014-7020.

Miyazaki, H., Yanagida, N., Horinouchi, S. and Beppu, T. (1989). Characterization of the precursor of Serratia marcescens serine protease and $\mathrm{COOH}$-terminal processing of the precursor during its excretion through the outer membrane of Escherichia coli. J. Bacteriol. 171, 6566-6572.

Mori, H. and Ito, K. (2001). The Sec protein-translocation pathway. Trends Microbiol. 9, 494-500.

Morona, R. and Van Den Bosch, L. (2003). Multicopy icsA is able to suppress the virulence defect caused by the wzz(SF) mutation in Shigella flexneri. FEMS Microbiol. Lett. 221, 213-219.

Muller, M., Koch, H.G., Beck, K. and Schafer, U. (2001). Protein traffic in bacteria, multiple routes from the ribosome to and across the membrane. Prog Nucleic Acid Res Mol Biol. 66, 107-157.

Murzin, A.G., Lesk, A.M. and Chothia, C. (1994a). Principles determining the structure of $\beta$-sheet barrels in proteins. I. A theoretical analysis. J. Mol. Biol. 236, 1369-1381.

Murzin, A.G., Lesk, A.M. and Chothia, C. (1994b). Principles determining the structure of $\beta$-sheet barrels in proteins. II. The observed structures. J. Mol. Biol. 236, 1382-1400.

Nielsen, H., Brunak, S. and von Heijne, G. (1999). Machine learning approaches for the prediction of signal peptides and other protein sorting signals. Protein Eng. 12, 3-9.

Nikaido, H. (1992). Porins and specific channels of bacterial outer membranes. Mol. Microbiol. 6, 435-442.

Nikaido, H. (1994). Porins and specific diffusion channels in bacterial outer membranes. J. Biol. Chem. 269, 39053908.

Nummelin, H., Merckel, M.C., el Tahir, Y., Ollikka, P., Skurnik, M. and Goldman, A. (2003). Structural studies of Yersinia adhesin YadA. Adv Exp Med Biol. 529, 85-88.

Odenbreit, S., Till, M., Hofreuter, D., Faller, G. and Haas, R. (1999). Genetic and functional characterization of the alpAB gene locus essential for the adhesion of Helicobacter pylori to human gastric tissue. Mol. Microbiol. 31, 1537-1548.

Ohnishi, Y., Nishiyama, M., Horinouchi, S. and Beppu, T. (1994). Involvement of the $\mathrm{COOH}$-terminal pro-sequence of Serratia marcescens serine protease in the folding of the mature enzyme. J. Biol. Chem. 269, 32800-32806.

Oliver, D.C., Huang, G. and Fernandez, R.C. (2003a). Identification of secretion determinants of the Bordetella pertussis BrkA autotransporter. J. Bacteriol. 185, 489495.

Oliver, D.C., Huang, G., Nodel, E., Pleasance, S. and Fernandez, R.C. (2003b). A conserved region within the Bordetella pertussis autotransporter BrkA is necessary for folding of its passenger domain. Mol. Microbiol. 47, 1367-1383.

Owen, P., Meehan, M., de Loughry-Doherty, H. and Henderson, I.R. (1996). Phase-variable outer membrane proteins in Escherichia coli. FEMS Immunol. Med. Microbiol. 16, 63-76.

Peterson, J.H., Woolhead, C.A. and Bernstein, H.D. (2003). Basic amino acids in a distinct subset of signal peptides promote interaction with the signal recognition particle. J. Biol. Chem. 29,( Papers In Press, published online ahead of print August 29, 2003).

Pohlner, J., Halter, R., Beyreuther, K. and Meyer, T.F. (1987). Gene structure and extracellular secretion of Neisseria gonorrhoeae IgA protease. Nature. 325, 458462.

Pugsley, A.P. (1993). The complete general secretory pathway in Gram-negative bacteria. Microbiol. Rev. 57, 50-108.

Purdy, G.E., Hong, M. and Payne, S.M. (2002). Shigella flexneri DegP facilitates IcsA surface expression and is required for efficient intercellular spread. Infect. Immun. 70, 6355-6364.

Qi, H.Y., Hyndman, J.B. and Bernstein, H.D. (2002). DnaK promotes the selective export of outer membrane protein precursors in SecA-deficient Escherichia coli. J. Biol. Chem. 277, 51077-51083.

Randall, L.L. and Hardy, S.J. (2002). SecB, one small chaperone in the complex milieu of the cell. Cell Mol. Life Sci. 59, 1617-1623.

Randall, L.L., Topping, T.B., Suciu, D. and Hardy, S.J. (1998). Calorimetric analyses of the interaction between SecB and its ligands. Protein Sci. 7, 1195-1200.

Renauld-Mongenie, G., Cornette, J., Mielcarek, N., Menozzi, F.D. and Locht, C. (1996). Distinct roles of the $\mathrm{N}$-terminal and $\mathrm{C}$-terminal precursor domains in the biogenesis of the Bordetella pertussis filamentous 
hemagglutinin. J. Bacteriol. 178, 1053-1060.

Roggenkamp, A., Ackermann, N., Jacobi, C.A., Truelzsch, K., Hoffmann, H. and Heesemann, J. (2003). Molecular analysis of transport and oligomerization of the Yersinia enterocolitica adhesin YadA. J. Bacteriol. 185, 37353744.

Salmond, G.P. and Reeves, P.J. (1993). Membrane traffic wardens and protein secretion in Gram-negative bacteria. Trends Biochem. Sci. 18, 7-12.

Samuelson, J.C., Chen, M., Jiang, F., Moller, I., Wiedmann, M., Kuhn, A., Phillips, G.J. and Dalbey, R.E.( 2000). YidC mediates membrane protein insertion in bacteria. Nature. 406, 637-641.

Sandkvist, M. (2001). Biology of type II secretion. Mol. Microbiol. 40, 271-283.

Sapriel, G., Wandersman, C. and Delepelaire, P. (2003). The SecB chaperone is bifunctional in Serratia marcescens, SecB is involved in the Sec pathway and required for Has $A$ secretion by the $A B C$ transporter. J. Bacteriol. 185, 80-88.

Schonherr, R., Tsolis, R., Focareta, T. and Braun, V. (1993). Amino acid replacements in the Serratia marcescens haemolysin ShIA define sites involved in activation and secretion. Mol. Microbiol. 9, 1229-1237.

Schulz, G.E. (2003). Transmembrane beta-barrel proteins. Adv. Protein Chem. 63, 47-70.

Serruto, D., Adu-Bobie, J., Scarselli, M., Veggi, D., Pizza, M., Rappuoli, R. and Arico, B. (2003). Neisseria meningitidis App, a new adhesin with autocatalytic serine protease activity. Mol. Microbiol. 48, 323-334.

Sexton, J.A. and Vogel, J.P. (2002). Type IVB secretion by intracellular pathogens. Traffic. 3, 178-185.

Shannon, J.L. and Fernandez, R.C. (1999). The C-terminal domain of the Bordetella pertussis autotransporter BrkA forms a pore in lipid bilayer membranes. J. Bacteriol. 181, 5838-5842.

Shere, K.D., Sallustio, S., Manessis, A., D'Aversa, T.G. and Goldberg, M.B. (1997). Disruption of IcsP, the major Shigella protease that cleaves IcsA, accelerates actinbased motility. Mol. Microbiol. 25, 451-462.

Sijbrandi, R., Urbanus, M.L., ten Hagen-Jongman, C.M., Bernstein, H.D., Oudega, B., Otto, B.R. and Luirink, J. (2003). Signal recognition particle (SRP)-mediated targeting and Sec-dependent translocation of an extracellular Escherichia coli protein. J. Biol. Chem. 278, 4654-4659.

St Geme, J.W., 3rd and Cutter, D. (2000). The Haemophilus influenzae Hia adhesin is an autotransporter protein that remains uncleaved at the $C$ terminus and fully cell associated. J. Bacteriol. 182, 6005-6013.

Stathopoulos, C., Hendrixson, D.R., Thanassi, D.G., Hultgren, S.J., St Geme, J.W., 3rd and Curtiss, R., 3rd. (2000). Secretion of virulence determinants by the general secretory pathway in Gram-negative pathogens, an evolving story. Microbes. Infect. 2, 1061-1072.

Steinhauer, J., Agha, R., Pham, T., Varga, A.W. and Goldberg, M.B. (1999). The unipolar Shigella surface protein IcsA is targeted directly to the bacterial old pole, IcsP cleavage of IcsA occurs over the entire bacterial surface. Mol. Microbiol. 32, 367-377.

Struyve, M., Moons, M. and Tommassen, J. (1991). Carboxy-terminal phenylalanine is essential for the correct assembly of a bacterial outer membrane protein.
J. Mol. Biol. 218, 141-148.

Szabady, R.L. and Bernstein, H.D. (2003). Function of the unusual signal peptide of the autotransporter protein EspP. In, 103th General Meeting. Washington D.C., American Society of Microbiology.

Tamm, A., Tarkkanen, A.M., Korhonen, T.K., Kuusela, P., Toivanen, P. and Skurnik, M. (1993). Hydrophobic domains affect the collagen-binding specificity and surface polymerization as well as the virulence potential of the YadA protein of Yersinia enterocolitica. Mol. Microbiol. 10, 995-1011.

Tamm, L.K., Arora, A. and Kleinschmidt, J.H. (2001). Structure and assembly of beta-barrel membrane proteins. J. Biol. Chem. 276, 32399-32402.

Thanassi, D.G. (2002). Ushers and secretins, channels for the secretion of folded proteins across the bacterial outer membrane. J. Mol. Microbiol. Biotechnol. 4, 11-20.

Thanassi, D.G. and Hultgren, S.J. (2000). Multiple pathways allow protein secretion across the bacterial outer membrane. Curr. Opin. Cell Biol. 12, 420-430.

Turner, D.P., Wooldridge, K.G. and Ala'Aldeen, D.A. (2002). Autotransported serine protease A of Neisseria meningitidis, an immunogenic, surface-exposed outer membrane, and secreted protein. Infect. Immun. 70, 4447-4461.

Valent, Q.A. (2001). Signal recognition particle mediated protein targeting in Escherichia coli. Antonie Van Leeuwenhoek. 79, 17-31.

Valent, Q.A., Scotti, P.A., High, S., de Gier, J.W., von Heijne, G., Lentzen, G., Wintermeyer, W., Oudega, B. and Luirink, J. (1998). The Escherichia coli SRP and SecB targeting pathways converge at the translocon. EMBO J. 17, 2504-2512.

Valls, M., Atrian, S., de Lorenzo, V. and Fernandez, L.A. (2000). Engineering a mouse metallothionein on the cell surface of Ralstonia eutropha $\mathrm{CH} 34$ for immobilization of heavy metals in soil. Nat. Biotechnol. 18, 661-665.

Veiga, E., de Lorenzo, V. and Fernandez, L.A. (1999). Probing secretion and translocation of a betaautotransporter using a reporter single-chain Fv as a cognate passenger domain. Mol. Microbiol. 33, 12321243.

Veiga, E., Sugawara, E., Nikaido, H., de Lorenzo, V. and Fernandez, L.A. (2002). Export of autotransported proteins proceeds through an oligomeric ring shaped by C-terminal domains. EMBO J. 21, 2122-2131.

von Heijne, G. (1998). Life and death of a signal peptide. Nature. 396, 111-113.

Voulhoux, R., Bos, M.P., Geurtsen, J., Mols, M. and Tommassen, J. (2003). Role of a highly conserved bacterial protein in outer membrane protein assembly. Science. 299, 262-265.

Watanabe, M. and Blobel, G. (1989). SecB functions as a cytosolic signal recognition factor for protein export in Escherichia coli. Cell. 58, 695-705.

Watanabe, M. and Blobel, G. (1995). High-affinity binding of Escherichia coli SecB to the signal sequence region of a presecretory protein. Proc. Natl. Acad. Sci. U S A. 92, 10133-10136.

Yen, M.R., Peabody, C.R., Partovi, S.M., Zhai, Y., Tseng, Y.H. and Saier, M.H. (2002). Protein-translocating outer membrane porins of Gram-negative bacteria. Biochim. Biophys. Acta. 1562, 6-31. 


\section{Further Reading}

Caister Academic Press is a leading academic publisher of advanced texts in microbiology, molecular biology and medical research. Full details of all our publications at caister.com

- MALDI-TOF Mass Spectrometry in Microbiology Edited by: M Kostrzewa, S Schubert (2016) www.caister.com/malditof

- Aspergillus and Penicillium in the Post-genomic Era Edited by: RP Vries, IB Gelber, MR Andersen (2016) www.caister.com/aspergillus2

- The Bacteriocins: Current Knowledge and Future Prospects Edited by: RL Dorit, SM Roy, MA Riley (2016)

www.caister.com/bacteriocins

- Omics in Plant Disease Resistance Edited by: V Bhadauria (2016) www.caister.com/opd

- Acidophiles: Life in Extremely Acidic Environments Edited by: R Quatrini, DB Johnson (2016) www.caister.com/acidophiles

- Climate Change and Microbial Ecology: Current Research and Future Trend

Edited by: J Marxsen (2016)

www.caister.com/climate

- Biofilms in Bioremediation: Current Research and Emerging Technologies

Edited by: G Lear (2016)

www.caister.com/biorem

- Microalgae: Current Research and Applications Edited by: MN Tsaloglou (2016) www.caister.com/microalgae

- Gas Plasma Sterilization in Microbiology: Theory, Applications, Pitfalls and New Perspectives Edited by: H Shintani, A Sakudo (2016) www.caister.com/gasplasma

- Virus Evolution: Current Research and Future Directions Edited by: SC Weaver, M Denison, M Roossinck, et al. (2016) www.caister.com/virusevol

- Arboviruses: Molecular Biology, Evolution and Control Edited by: N Vasilakis, DJ Gubler (2016) www.caister.com/arbo

- Shigella: Molecular and Cellular Biology Edited by: WD Picking, WL Picking (2016) www.caister.com/shigella

-Aquatic Biofilms: Ecology, Water Quality and Wastewater Treatment

Edited by: AM Romaní, H Guasch, MD Balaguer (2016)

www.caister.com/aquaticbiofilms

- Alphaviruses: Current Biology

Edited by: S Mahalingam, L Herrero, B Herring (2016)

www.caister.com/alpha

- Thermophilic Microorganisms

Edited by: F Li (2015)

www.caister.com/thermophile
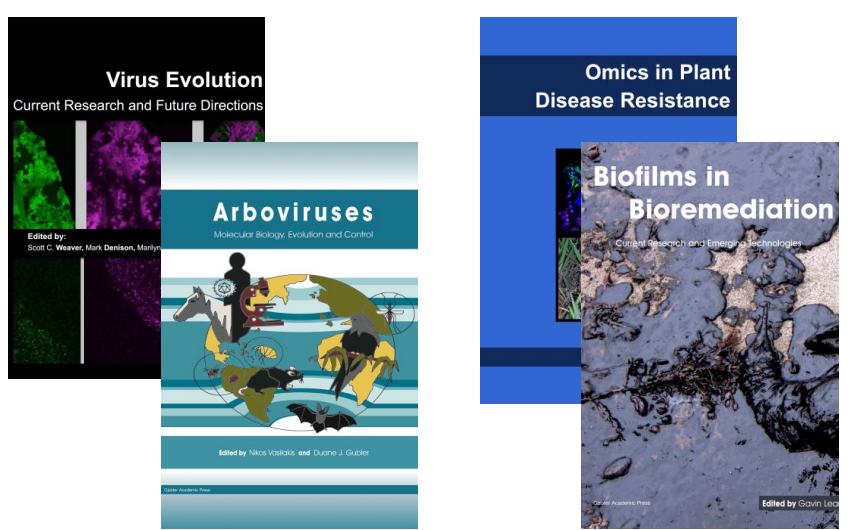
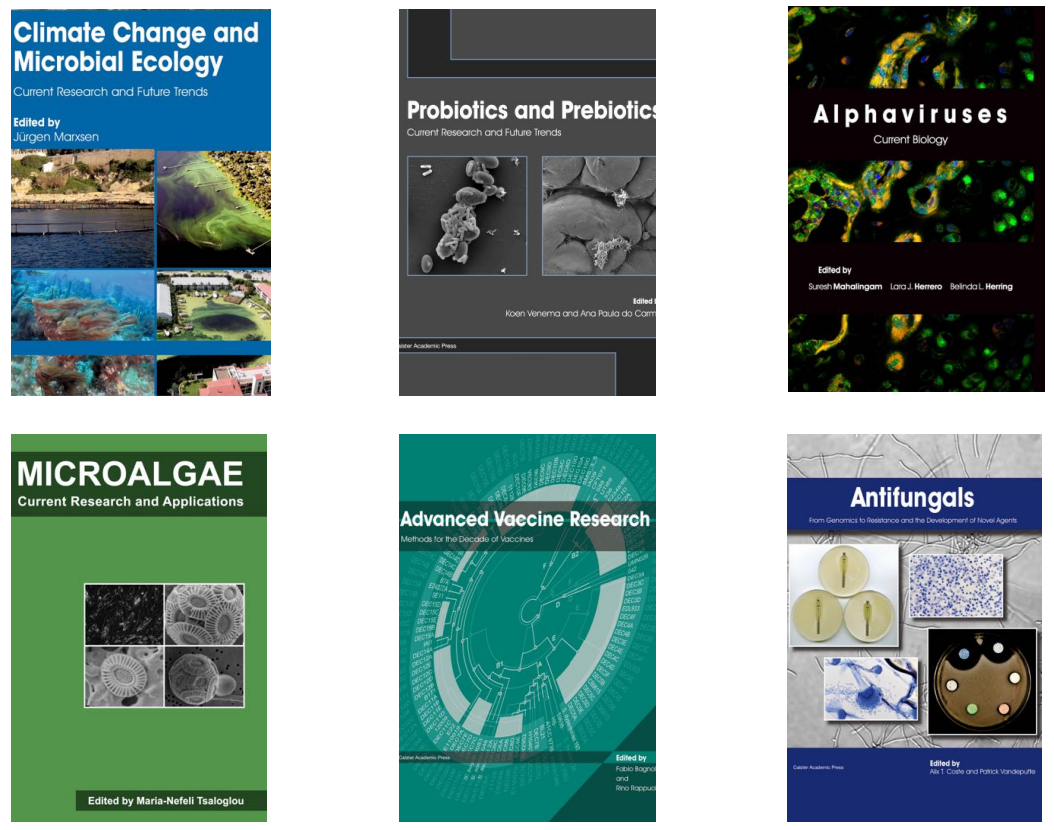

- Flow Cytometry in Microbiology: Technology and Applications Edited by: MG Wilkinson (2015) www.caister.com/flow

- Probiotics and Prebiotics: Current Research and Future Trends Edited by: K Venema, AP Carmo (2015) www.caister.com/probiotics

- Epigenetics: Current Research and Emerging Trends Edited by: BP Chadwick (2015) www.caister.com/epigenetics2015

- Corynebacterium glutamicum: From Systems Biology to Biotechnological Applications

Edited by: A Burkovski (2015)

www.caister.com/cory2

- Advanced Vaccine Research Methods for the Decade of Vaccines

Edited by: F Bagnoli, R Rappuoli (2015)

www.caister.com/vaccines

- Antifungals: From Genomics to Resistance and the Development of Novel Agents

Edited by: AT Coste, P Vandeputte (2015)

www.caister.com/antifungals

- Bacteria-Plant Interactions: Advanced Research and Future Trends Edited by: J Murillo, BA Vinatzer, RW Jackson, et al. (2015) www.caister.com/bacteria-plant

\section{- Aeromonas}

Edited by: J Graf (2015)

www.caister.com/aeromonas

- Antibiotics: Current Innovations and Future Trends

Edited by: S Sánchez, AL Demain (2015)

www.caister.com/antibiotics

- Leishmania: Current Biology and Contro Edited by: S Adak, R Datta (2015) www.caister.com/leish2

- Acanthamoeba: Biology and Pathogenesis (2nd edition) Author: NA Khan (2015)

www.caister.com/acanthamoeba2

- Microarrays: Current Technology, Innovations and Applications Edited by: Z He (2014)

www.caister.com/microarrays2

- Metagenomics of the Microbial Nitrogen Cycle: Theory, Methods and Applications

Edited by: D Marco (2014)

www.caister.com/n2 